\title{
COMMISSIONED WORKS AS WORKS MADE FOR HIRE UNDER THE 1976 COPYRIGHT ACT: MISINTERPRETATION AND INJUSTICE
}

\author{
Marci A. Hamilton $\dagger$
}

The Copyright Act of 1976 ("1976 Act") has been unflatteringly described "as an immensely complex package of expedients and compromises altogether unillumined by any conceptual thought or principle." In fact, the revision process which gave rise to the 1976 Act was not predominated by scholars, evoking timeless principles against which each new provision was measured. Rather, in a robustly American way, it was the product of the striking of a series of compromises over an extended period of time. ${ }^{3}$ For the drafters,

[T] here was no single model for anything. The basic drafting approach was to decide what to say and then to say it .... [Since the proposals] reflected deliberate choices between alternatives, based on past proposals from contending interests, the Copyright Office's initial drafts were in fact compromises even before they met the light of day. ${ }^{4}$

The work-made-for-hire ${ }^{\mathbf{5}}$ provisions with respect to commissioned works provide one of the clearest examples of the copyright revision's compromise process. From the first preliminary draft of the 1976 Act in which no commissioned works would have been considered as works made for hire to the final version in which nine categories of commissioned works had been added to the work-made-for-hire provisions,

$\dagger$ B.A. (English \& Philosophy) 1979, Vanderbilt University; M.A. (Philosophy) 1982, M.A. (English) 1984, The Pennsylvania State University; J.D. Candidate 1988, University of Pennsylvania. (1982)).

1 Pub. L. No. 94-553, 90 Stat. 2541 (1976) (codified at 17 U.S.C. $\$ \S 101-810$

2 Whale, Copyright and Authors Rights, Eur. Intell. Prop. Rev., Feb. 1979, at $38,38-39$. (1977).

3 Ringer, First Thoughts on the Copyright Act of 1976, 13 Copyright 187, 188

Id.

- The precise definition of "work made for hire" under the 1976 Act is at issue in this Comment, but generally, the term refers to works created by employees within the context of an employment relationship. The term is also applicable to certain types of independent contractors. See infra notes 75-81 and accompanying text. Commissioned works are those works prepared by independent contractors pursuant to agreement with a hiring party. 
publishers and artists compromised, debated, and entered into further compromises. But the compromises were based upon the publishers' and artists' conjectures about the operation of the provisions. The practical import of the compromises could not be known until the law went into effect in 1978. While publishers have by and large been pleased with the treatment of commissioned works under the 1976 Act, artists have become increasingly disenchanted with the operation of the 1976 Act's commissioned work-made-for-hire provisions. ${ }^{6}$

This Comment argues that the 1976 Act's work-made-for-hire provisions should be amended to provide greater protection for commissioned artists creating what are now considered works made for hire. Part.I discusses the work-made-for-hire provisions in the Copyright Act of 1909 ("1909 Act") $)^{7}$ and their judicial interpretation. Part II recounts the legislative history leading up to the work-made-for-hire provisions governing commissioned works under the 1976 Act. In addition, it delineates the two judicial interpretations that have been advanced, arguing that one obviates the 1976 amendments. Part III chronicles how the 1976 Act has failed to provide adequate protection for the creators of commissioned works and proposes legislative amendments that would remedy the shortcomings of the present Act.

\section{Historical Background of the Work-MAde-For-Hire Provisions}

\section{A. 1909 Copyright Law Provisions Governing Works Made for Hire}

Congress's power to grant copyright in artistic works can be found in article 1, section 8 of the Constitution, which states that Congress has power " $[\mathrm{t}] \mathrm{o}$ promote the Progress of Science and useful Arts, by securing for limited Times to Authors and Inventors the exclusive Right to their respective Writings and Discoveries."8 The Constitution thereby grounds United States copyright law in a tension between stimulating the artist to create and limiting the artist's monopoly in the work. ${ }^{9}$ One way to understand the essence of the constitutional directive

6 See, e.g., Haynes, The Copyright Law: Seeking a Change for the Free-lancer, Phila. Inquirer, Jan. 25, 1987, (Books/Leisure), at 16, col. 1 ("The new law didn't work the way everybody thought it would. . ..").

7 Pub. L. No. 60-349, 60 Stat. 1075 (1909), repealed by Pub. L. No. 94-553, 90 Stat. 2541 (1976) (codified at 17 U.S.C. $\$ \S 101-810$ (1982)).

8 U.S. Const. art. I, $\S 8$, cl. 8.

9 As two congressional reports on copyright law have stated:

The enactment of copyright legislation by Congress under the terms of the constitution is not based upon any natural right that the author has in his 
is to contrast it with the laws of a country in which moral or personal rights rather than economic rights are the focus of copyright protection. For example, in the French system of copyright, an author's right to copyright resides in notions akin to natural rights. The artist has legally enforceable personal rights in the work; mere creation of the work, not the public benefit drawn from creation, forms the ground on which an author is protected. ${ }^{10}$ Although Congress between the 1909 Act and the 1976 Act subtly shifted the focus from public benefit to author remuneration, ${ }^{11}$ United States copyright law still exists primarily to serve the public by ensuring the maximal amount of artistic production.

Prior to passage of the 1909 Act, $^{12}$ no explicit statutory provisions dealt with works made for hire or works made under commission. At common law, however, there was a presumption of the employer's ownership of the copyright. An artist working under commission could retain copyright in her works only by reserving those rights pursuant to contract. ${ }^{13}$ For example, in Dielman $v$. White, ${ }^{14}$ decided in 1900 , the Circuit Court of the District of Massachusetts stated:

[W] hen an artist is commissioned to execute a work of art not in existence at the time the commission is given, the burden of proving that he retains a copyright in the work of art executed, sold, and delivered under the commission rests heavily upon the artist himself. If a patron gives a commis-

writings ... but upon the ground that the welfare of the public will be served and progress of science and useful arts will be promoted . . . . In enacting a copyright law Congress must consider . . . two questions: First, how much will the legislation stimulate the producer and so benefit the public and, second, how much will the monopoly granted be detrimental to the public?

Register of Copyrights, 87Th Cong., 1ST Sess., Copyright Law Revision 5 (Comm. Print 1961) (quoting H.R. REP. No. 2222, 60th Cong., 2d Sess. 7 (1909)); see also Mazer v. Stein, 347 U.S. 201, 219 (1954) ("The economic philosophy behind the [copyright clause of the Constitution] is the conviction that encouragement of individual effort by personal gain is the best way to advance public welfare . . ..").

${ }_{10}$ See Françon and Ginsburg, Authors' Rights in France: The Moral Right of the Creator of a Commissioned Work to Compel the Commissioning Party to Complete the Work, 9 Colum.-VLA J.L. \& ARTs 381, 383 (1985).

11 See infra notes 50-54 and accompanying text (discussing the 1976 Act's concern that authors receive their just reward).

12 For a brief, but accurate history of copyright law leading up to the Constitution and through the 1909 hearings, see Fred Fisher Music Co. v. M. Witmark \& Sons, 318 U.S. 643, 647-56 (1943).

is See, e.g., Yardley v. Houghton Mifflin Co., Inc., 108 F.2d 28, 31 (2d Cir. 1939) (common law rule is that copyright passes to parton unless arist can prove the parties intended otherwise).

14102 F. 892 (C.C.D. Mass. 1900). 
sion to an artist, there appears to me a very strong implication that the work of art commissioned is to belong unreservedly and without limitation to the patron . . . .

[However] it is doubtless possible, by apt expressions in the contract, for the artist to retain the copyright for himself. ${ }^{16}$

During the hearings culminating in the 1909 Act, the seeds for the current work-made-for-hire provisions (and controversies) were planted. First, the principle was advanced that the payment of a salary to an employee "entitle[d] an employer to all rights to obtain a copyright in any work performed during the hours for which such salary [was] paid."16 In other words, the salaried employee, implicitly the fulltime employee, should automatically lose rights in her work. Second, a distinction was made between employees and independent artists:

[T]he right belonging to that artist who is employed for the purpose of making a work of art so many hours a day, or that literary producer who is employed for so many hours, should be very different from the right that is held by the independent artist or man who makes a painting for art's sake. ${ }^{17}$

This recognition of a difference between independent contractors and salaried employees gave rise to a controversy that continues to haunt the work-made-for-hire provisions to this day: how does one distinguish the employee from the independent artist? The 1909 Act provided little guidance to the court trying to make this decision; it merely stated that "the word 'author' shall include an employer in the case of works made for hire."18 During the amendment process, these difficulties were recognized, and a full definition clause was requested to clarify this and

16 Id. at 894-95.

${ }^{16}$ Stenographic Report of the Proceedings of the Librarian's Conf. on Copyright, 2d Sess. 65 (Nov. 1-4, 1905) [hereinafter Librarian's Conf.], reprinted in 2 LEGISLATIVE History OF THE 1909 Copyright ACT at 65 (E. Brylawski \& A. Goldman eds. 1976) [hereinafter Legrslative HistoRy] (statement of Mr. A.W. Elson of A.W. Elson \& Co., educational art publishers). Salary did not persist as the sole criterion of the employer's investment. See Note, The Freelancer's Trap: Work for Hire Under the Copyright Act of 1976, 86 W. VA. L. REv. 1305, 1315-16 (1984) (analyzing case law developments and legislative proposals concerning the 1976 Act's work-made-for-hire provisions up to 1984).

${ }^{17}$ Librarian's Conf., supra note 16, at 188 (statement of Mr. A. Beverly Smith, Lithographers' Ass'n (East)), reprinted in 2 LEGISLATIVE HISTORY supra, note 16, at 188.

1817 U.S.C. $\$ 26$ (repealed 1976). 
similar vague or uncertain terms. ${ }^{10}$ But no definition clause was ever added.

The legislative history of the work-made-for-hire provisions in the 1909 Act reveals that participants in the amendment process distinguished between employees, in the customary sense of the word, and independent contractors. ${ }^{20}$ Nevertheless, courts eventually declined to spend the time drawing such distinctions. In the early cases involving commissioned works, the courts generally applied the Dielman standard: in the absence of evidence to the contrary, the copyright was presumed to vest in the commissioning party. ${ }^{21}$ The early employer-employee cases, on the other hand, developed several tests to determine whether an employment relationship existed. ${ }^{22}$ By the mid-1960's, however, courts were applying the tests developed for employer-employee cases to cases involving independent contractors.

In 1966, in the seminal case involving independent contractors, Brattleboro Publishing Co. v. Winmill Publishing Corp. ${ }^{23}$ the Court of Appeals for the Second Circuit stated that the work-made-for-hire doctrine applied "whenever an employee's work is produced at the instance and expense of his employer." could "see no sound reason why these same principles [regarding works created by a salaried employee] are not applicable when the parties bear the relationship of employer and independent contractor." ${ }^{25}$ Six

19 See Miscellaneous Amends. to S. 6330 and H.R. 19853 Proposed to the Copyright Office, reprinted in 5 Legislative HistoRy, supra note 16, at M55 (amendment proposed by Mr. H. Bentwich).

${ }_{20}$ See supra note 17 and accompanying text. After passage of the 1909 Act, the majority of the early cases involving commissioned works concerned photographs, especially portraits. See Staff of Subcomm. on Patents, Trademarks, and Copyrights of the Senate Comm. on the Judiciary, 86Th Cong., 1st Sess., CopyRIght Law Revision, Study 13, 127, 130 (Comm. Print 1960) (report by B. Varmer), reprinted in 1 STUDIES ON Copyright 717, 722 (The Copyright Society of U.S.A. eds. 1963) [hereinafter VARMER]; see, e.g., Lumiere v. Robertson-Cole Distributing Corp., 280 F. 550 (2d Cir.), cert. denied, 259 U.S. 583 (1922); Altman v. New Haven Union Co., 254 F. 113 (D. Conn. 1918). In the photography cases, the courts focused on the relationship between the parties to determine their respective rights in copyright. Therefore, although the courts held that the contract implied that the portrait's copyright resided in the sitter, when "the photograph is taken at the expense of the photographer and for his benefit, the sitter loses control of the disposition of the pictures, and the property right is in the photographer." Altman, $254 \mathrm{~F}$. at 118.

$211 \mathrm{M}$. NimMER, NimMer ON CopYright $\S 5.03(\mathrm{~B})(2)(\mathrm{c})$, at 5-21 (23d ed. 1986).

${ }^{22}$ See generally Note, supra note 16 , at 1313-16.

2s 369 F.2d 565 (2d Cir. 1966) (holding that in absence of express agreement to the contrary, copyright resides in advertisers paying newspaper's employees to create ads, not in newspaper).

24 Id. at 567.

28 Id. at 568 . 
years later, in Picture Music, Inc. v. Bourne, Inc. ${ }^{26}$ the Second Circuit again refused to distinguish between employees and independent contractors, asserting that: "[ $t]$ he purpose of the statute is not to be frustrated by conceptualistic formulations of the employment relationship."27 Thus, because of the courts' refusal to plug the gap left by Congress's failure to define "employer," the same standards applied to employees' works made for hire were eventually applied to commissioned works made for hire. ${ }^{28}$

Of those tests devised by the courts to apply the work-made-forhire provisions of the 1909 Act, $^{29}$ the one most relevant to this Comment concerns the employer's right to supervise. ${ }^{30}$ The majority and the dissent in Scherr $v$. Universal Match Corp..$^{31}$ delineated the two ways of analyzing the supervision issue. In Scherr, two ex-servicemen brought a copyright infringement suit against a matchbook manufacturer and the United States government. During their regular duty hours spent in the army as illustrators preparing visual aids for training, the plaintiffs created a statue to which they affixed a copyright notice. Several months after the unveiling, they registered their claim of copyright. $^{32}$ They sued when they discovered a picture of the statue on matchbooks. The Court of Appeals for the Second Circuit formulated the test to determine whether the statue was a work made for hire, stating, "The essential factor in determining whether an employee created his work of art within the scope of his employment as part of his employment duties is whether the employer possessed the right to direct and to supervise the manner in which the work was being per-

${ }^{28} 457$ F.2d 1213 (2d Cir.), cert. denied, 409 U.S. 997 (1972).

27 Id. at 1216.

${ }^{28}$ Lower federal courts are not the only courts to refuse to address the meaning of the 1909 Act's work-made-for-hire provisions. The Supreme Court has not addressed the work-made-for-hire issue since 1903, when it decided the landmark case of Bleistein v. Donaldson Lithographing Co., 188 U.S. 239, 248 (1903) (holding circus advertisement designs belong to employer because plaintiff's employees produced the advertisment). See Note, supra note 16, at 1318-19.

${ }^{29}$ For discussion of the various tests created by the courts, see Note, supra note 16 , at 1313-16.

so See infra notes 31-38 and accompanying text. In addition to the supervision test discussed throughout this Comment, another widely used test was the "instance and expense" test. See, e.g., Brattelboro, 369 F.2d at 567 ("[T]he "works for hire' doctrine . . . is applicable whenever an employee's work is produced at the instance and expense of his employer."). The instance and expense test was the judicial response to the 1909 Act drafters' notion that employers deserved copyright in works for which they supplied the salary, the overhead, and the incentive to create works. See supra notes 16-17 and accompanying text.

s1 417 F.2d 497 (2d Cir. 1969), cert. denied, 397 U.S. 936 (1970).

32 Id. at 498-99. Plaintiffs had begun work independently on the statue while serving as illustrators, but were subsequently requested by their deputy-commander to devote all of their duty hours to a larger version of the statue. Id. 
formed." 33 The court concluded that the government did possess such a right, even though its exercise of the right was "limited." The government's right to supervise in conjunction with its appropriation of funds, time, and facilities established that the work was a work made for hire. Therefore, the district court's dismissal of complainant's action was affirmed. ${ }^{\text {s4 }}$

In his dissent, Judge Friendly advocated a limited use of the supervision test to determine copyright ownership in situations where the employer's creative contribution was substantial. ${ }^{35}$ In short, he believed a supervision test was justified when the employer's creative input was substantial. Judge Friendly objected, however, to granting rights to employers in works made for hire when the employer made no significant creative contribution. In those cases, since the employer was no longer the creator, the supervision test was unjustified. ${ }^{36}$ Thus, he provided his own explanation of why copyright in a work should belong to the employer even if she did not exercise her right to supervision, such as in the cases of commissioned works. He stated that even when the employer did not exercise such control, it was "not unreasonable to assume ... that the parties expected the purchaser to wind up owning the work ... and that the artist set his price accordingly." ${ }^{37}$ Judge Friendly dissented in Scherr because he believed that the governmentserviceman relationship did not provide such a reasonable inference. In short, he objected to the use of the supervision test unless the quantum of the employer's input was substantial; when it was not, he urged the use of a rebuttable presumption of the parties' intent, strongly reminiscent of the Dielman standard. ${ }^{38}$

ss Id. at 500; see also Murray v. Gelderman, 566 F.2d 1307 (5th Cir. 1978) (emphasizing that the right to supervise, regardless of whether the right was in fact exercised, was determinative as to whether a work was a work made for hire under the 1909 Act).

s4 Scherr, 417 F.2d at 501.

ss $I d$. at 502 ("Where the employer in fact tells the employee pretty much what to do, vesting copyright in the former is wholly consistent with the policy of the Copyright Act since the creativity can be said to be primarily the employer's and the employee has simply carried out his instructions.") (Friendly, J., dissenting).

${ }^{38}$ Id.; $c f$. Samet v. Wells, 185 U.S.P.Q. 36 (E.D.N.Y. 1975) (holding supervision test inapplicable to commissioned works, which were presumed to be works made for hire).

s7 Scherr, 417 F.2d at 502 (Friendly, J., dissenting).

ss See id.; cf. supra note 15 and accompanying text (quoting the Dielman standard). The presumption of the parties' intent articulated by Judge Friendly in Scherr was adopted by other courts to determine if a work was a work made for hire. See, e.g., May v. Morganelli-Heumann \& Assoc., 618 F.2d 1363, 1368 (9th Cir. 1980) ("WW]hen an employer hires an employee or an independent contractor to produce work of an artistic nature, the courts will presume in the absence of contrary proof that the parties expected the employer to own the copyright and that the artist set his price 
Judge Friendly's dissenting opinion in Scherr represented a departure from existing law, since, under most judicial constructions of the 1909 Act, the extent of the employer's participation in the creation of the work was usually immaterial. In Shapiro, Bernstein \& Co. $v$. Bryan, ${ }^{39}$ for example, the employee argued that the meaning of the phrase, "work for hire," "does not include works of which employees are the real authors, but only those to which they made some ancillary contribution to the 'employer' who is the chief author."40 Judge Learned Hand refused to determine the work-made-for-hire issue according to the relative contributions of the employee and employer, stating that such a definition would reduce the application of the workmade-for-hire doctrine to only those situations in which the employee would have been a co-author, absent the work-made-for-hire provisions. He determined that "[t]he 'work' intended is clearly any 'work' which, but for the employment, the employee could have himself copyrighted; not a work in which his rights would have given him only a joint interest in the copyright." 11 On Judge Hand's terms, if the workmade-for-hire determination were based on the relative contributions of the employee and employer, then the reasoning would be no different from a determination of joint authorship, and the work-made-for-hire clause in the 1909 Act would have been redundant.

Under Judge Hand's reasoning, Judge Friendly's casting of the supervision test in terms of the quantum of the employer's contribution would have written the work-made-for-hire provisions out of the statute. Judge Friendly neatly side-stepped the work-made-for-fire issue altogether by adopting the joint ownership doctrine and invoking contract principles.

The Scherr majority, however, implemented the supervision test for the purpose of determining whether an employment relationship existed that could justify designation of the statue as a work made for hire according to the 1909 Act. ${ }^{42}$ Two commentators later described the majority's use of the supervision test to identify an employment relationship:

The right of the employer to direct and supervise the manner in which the work is performed has been deemed the

accordingly." (citing Scherr, 417 F.2d at 502 (Friendly, J., dissenting))).

s9 123 F.2d 697 (2d Cir. 1941).

$40 I d$. at 700 .

11 Id. Judge Hand referred to the employees' argument as "the merest invention, fabricated in the teeth of the statute." Id.

12 See Scherr, 417 F.2d at 501 (" "[I]f an employer-employee relationship between the Government and these plaintiffs actually existed, any ownership in the work designed by plaintiffs necessarily belongs to the Government."). 
"crucial question" and the "hallmark of "an employment for hire' relationship." Consequently, when an alleged employer does not have the right to direct, control, or supervise the work of an author, there exists no employment relationship. ${ }^{43}$

\section{B. Revision of the 1909 Copyright Act: Creating Copyright Law Anew}

While the courts refused to recognize the distinction between commissioned works and those made within an employment relationship, ${ }^{44}$ a variety of bills were introduced that would have excluded commissioned works from operation of the work-made-for-hire provisions. ${ }^{45}$ In his 1958 study prepared for the Subcommittee on Patents, Trademarks, and Copyrights as part of the copyright law revision begun in the 1950's, Borge Varmer asserted that there was little reason to change the copyright law by mentioning commissioned works, largely because the only cases concerning commissioned works decided up to that time under the 1909 Act were the photographer/sitter cases. ${ }^{48}$ Although he did not advocate adopting a separate rule for commissioned works, ${ }^{47}$ he stated that such a rule could be justified on the grounds that "the common law generally has differentiated between the employer-employee relationship and that of the parties to a contract for a commissioned product." ${ }^{38}$ According to Varmer, such a distinction was acceptable because an employer usually provides "more direction and exercises more

4s Angel \& Tannenbaum, Works Made for Hire Under S. 22, 22 N.Y.L. ScH. L. Rev. 209, 223 (1976) (quoting Epoch Producing Corp. v. Killiam Shows, Inc., 522 F.2d 737, 744 (2d Cir. 1975) (finding evidence insufficient to prove there was adequate supervision to constitute relationship making works at issue works made for hire), cert. denied, 424 U.S. 955 (1976) and 1 M. Nimmer, NimMER ON Copyright $\S 62.2$, at 238.2-239 (14th ed. 1976)).

14 See supra notes $23-28$ and accompanying text.

45 See VARMER, supra note 20, at 131-35.

46 See id. at 130. Varmer's report was written before the Second Circuit's decision in Brattleboro Publishing Co. v. Winmill Publishing Corp., 369 F.2d 565 (2d Cir. 1966), which greatly expanded the application of the work-made-for-hire doctrine to commissioned works. See supra notes 23-25 and accompanying text (discussing the Brattleboro decision). For a discussion of the photographer/sitter cases, see supra note 20.

17 Varmer's analysis, focusing on the right of the commissioning party to supervise the work, in many ways foreshadows the test adopted by the majority in Scherr. Compare Scherr, 417 F.2d at 500 (majority work-made-for-hire test) with VARMER, supra note 20 , at 142 ("Both classes of works [employee and commissioned] are produced for, pursuant to the initiative and order of, and against payment by, a person other than the creator.").

48 VARMER, supra note 20, at 142. 
control over the work of his employee than does a commissioner with respect to the work of an independent contractor." ${ }^{49} \mathrm{He}$ thus foreshadowed the Scherr dissent's consideration of the amount of the employer's supervision as a criterion for determining whether a work was a work made for hire.

The copyright law revision begun in the 1950's lasted for more than twenty years. It is perhaps most important to an interpretation of the provisions of the 1976 Act to comprehend the nature of the project the Copyright Office and eventually Congress undertook in revising the copyright law. Congress intended not merely to amend the 1909 Act, but rather to overhaul the copyright law. Ms. Barbara Ringer, Register of Copyrights at the time, observed:

When it was originally drafted in the early 1960's, the bill that eventually became the Act of 1976 was not based on pre-existing legislation, least of all the Act of 1909. Before embarking on its drafting efforts the Copyright Office had engaged in an extensive research project... . These studies included consideration of the history and wording of the copyright statutes of other countries, of international conventions on copyright, and of the long series of earlier revision bills....

[The Act's provisions] reflected deliberate choices between alternatives ....

Thus, the Copyright Office and Congress envisioned their project as one that would establish a "new" copyright system. With a new system of copyright came a somewhat different set of purposes. From very early in the revision process, the central purpose of the copyright law was not only to benefit the public welfare, but also to "give authors the reward due them for their contribution to society." 1 While the legislative history of the 1909 Act reveals concern over whether the legislation would "stimulate the producer and so benefit the public,"s2 the Report of the Register of Copyrights in 1961 suggested a subtle shift in the focus to the creator:

While some limitations and conditions on copyright are essential in the public interest, they should not be so burden-

49 Id.

so Ringer, supra note 3 , at 188 .

51 REGISTER OF COPYRIGHTS, supra note 9, at 5 (discussing the purposes of copyright law).

${ }_{52}$ Id. 
some and strict as to deprive authors of their just reward. ... [The creators'] rights should be broad enough to give them a fair share of the revenue to be derived from the market for their works. ${ }^{\text {s3 }}$

This new market approach is particularly relevant to the work-madefor-hire provisions with regard to the treatment of commissioned works in the 1976 Act. $^{54}$

"The status of works prepared on . . . commission was a major issue in the development of the definition of 'works made for hire' in

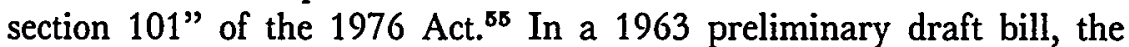
Copyright Office defined "work made for hire" as " "a work prepared by an employee within the scope of the duties of his employment, but not including a work made on special order or commission." "Bs Thus, contrary to the case law interpreting the 1909 Act, no commissioned works would have been deemed works made for hire. The complete exclusion of commissioned works from the work-made-for-hire doctrine, however, was met with strong opposition on the part of book publishers and motion picture producers.

These opponents of the exclusion of commissioned works from work-made-for-hire treatment argued that "in the case of a wide range of works . . . the distinction between 'employment' or 'commission' is fundamentally meaningless, since in either case the work is prepared at

6s Id. at 6 .

s4 See infra notes 139-53 and accompanying text (describing how the 1976 Act's commissioned work-made-for-hire clauses have impeded the policy of providing fair compensation to artists). The congressional interest in artists receiving fair compensation, however, has been diluted somewhat by the Supreme Court. In Sony Corp. v. Universal City Studios, 464 U.S. 417 (1984), the Court stated:

The monopoly privileges that Congress may authorize are neither unlimited nor primarily designed to provide a special private benefit. Rather, the limited grant is a means by which an important public purpose may be achieved. It is intended to motivate the creative activity of authors and inventors by the provision of a special reward, and to allow the public access to the products of their genius after the limited period of exclusive control has expired.

"The copyright law . . . makes reward to the owner a secondary consideration. . . . It is said that reward to the author or artist serves to induce release to the public of the products of his creative genius."

Id. at 429 (quoting United States v. Paramount Pictures, 334 U.S. 131, 158 (1948)). Yet, even on the Supreme Court's terms, fair compensation to artists is one of the factors necessary to provide the greatest possible benefit to the public.

SB H.R. REP. No. 1476, 94th Cong., 2d Sess. 121, reprinted in 1976 U.S. CodE Cong. \& ADMIN. News 5659, 5737.

se Register of Copyrights, 89Th Cong., 1st Sess., Supplementary RePORT ON COPYright LAw Revision pt. 6, at 66 (Comm. Print 1965) [hereinafter SUPPLEMENTARY REPORT]. 
the employer's initiative and risk and under his direction," Varmer's reasoning and the test adopted by the Scherr majority. ${ }^{58}$ On a more practical level, they opposed the proposed change because, under the Act's termination provisions, an individual author could terminate her assignment after a period of years; the creator of a work made for hire, however, could never terminate the employer's rights to the work. $^{59}$ Artists were equally opposed to "any broad provision that would convert a commissioned work into a 'work made for hire' upon the artist's written agreement," stressing their weak bargaining positions. ${ }^{60}$

By 1965, a compromise had been reached-four categories of commissioned works could be considered works made for hire if the contracting parties agreed to the same in writing. ${ }^{61}$ The Report from the Register of Copyright made it clear, though, that "other works made on special order or commission would not come within the definition" of a work made for hire. ${ }^{62}$ By 1967, a further compromise had been reached, and four additional categories were added to the list of those commissioned works that could be considered as works made for hire upon written agreement. ${ }^{63}$ The categories agreed upon by 1967 constitute virtually all of the categories now in the 1976 Act. ${ }^{64}$ Both the Senate and House Reports on the final bill presented in 1976 stated: "The definition now provided by the bill represents a compromise which, in effect, spells out those specific categories of commissioned works that can be considered 'works made for hire' under certain circumstances. ${ }^{\text {"66 }}$ In short, from a preliminary draft that excluded all commis-

${ }^{87}$ H.R. ReP. No. 83, 90th Cong., 1st Sess. 86 (1967).

s8 See supra note 47.

${ }^{58}$ Section 203(a) provides, in part: "In the case of any work other than a work made for hire, the exclusive or nonexclusive grant of a transfer or license of copyright . . . is subject to termination . . ."17 U.S.C. \$203(a) (1982). The publishers of a work made for hire would retain copyright in the work for 75 years. See 17 U.S.C. $\S 302$ (c) (1982) (specifying statutory duration of copyright). Without the work-madefor-hire provisions, an artist who assigned all her rights in the work could terminate the assignment in 35 or 40 years, thus cutting the publisher's ownership time nearly in half. See 17 U.S.C. $\S 203($ a)(3) (1982).

${ }^{60}$ See H.R. ReP. No. 83, supra note 57, at 86; see also infra notes $139-53$ and accompanying text (describing the ability of large publishing houses to compel even established independent artists to sign work-made-for-hire contracts).

61 See SupPlementary RePORT, supra note 56, at 67-68. The four designated categories were contributions to collective works and motion pictures, translations, and supplementary works.

${ }^{62} \mathrm{Id}$.

6s See H.R. REP. No. 83, supra note 57 , at 87 . The four additional categories were compilations, instructional texts, tests, and atlases.

Gf. 17 U.S.C. $\$ 101$ (1982) (enumerating types of commissioned works that can be classified as works made for hire).

es S. ReP. No. 473, 94th Cong., 1st Sess. 105 (1976); H.R. REP. No. 1476, 94th 
sioned works from the work-made-for-hire rubric, the copyright law revision developed into a final bill wherein only certain, specified categories of commissioned works could be considered as works made for hire. ${ }^{66}$ Moreover, in those specific cases, the commissioned work could only be a work made for hire if the parties agreed to designate it a work made for hire in a writing signed by both parties. ${ }^{67}$

This was an unprecedented development in work-made-for-hire doctrine. Prior to the 1976 Act, courts had simply lumped commissioned works together with those created in an employment context in making their work-made-for-hire decisions. ${ }^{68}$ In the 1976 Act, however, Congress divided the work-made-for-hire doctrine between those works "created within the scope of . . . employment" cially ordered or commissioned."70 Furthermore, the amount of deliberation that went into enumerating which types of commissioned works could be treated like employee-created works made for hire indicates that Congress intended for there to be a meaningful distinction between employee-created and commissioned works. As a result, while case law relating to works made for hire in an employment context conceivably could remain viable, the case law relating to commissioned works could not. $^{71}$

The legislative history of the 1976 Act's work-made-for-hire provisions explicitly "adopt[ed] one of the basic principles of the [1909] law: that in the case of works made for hire the employer is considered the author of the work . . ."72 But the legislative history records no other explicit incorporation of prior law relating to works made for hire, legislative or court-made. While in a general revision statute, legislative silence might well mean that court-made law is to continue in force, in an Act conceived as a "radical ... departure" from prior

Cong., 2d Sess. 121, reprinted in 1976 Code Cong. \& ADMIN. NEws 5659, 5737 (emphasis added).

Bs $1 \mathrm{M}$. NIMMER, supra note 21 , at $\S 5.03(\mathrm{~B})(2)(\mathrm{a})$, at 5-18 to -20 .

${ }^{67}$ Id. at $\S 5.03(\mathrm{~B})(2)(\mathrm{b})$, at $5-20$ to -21 .

o8 See supra notes 23-27 and accompanying text (discussing courts' refusal to distinguish employee-created and commissioned works).

e9 17 U.S.C. $\S 101$ (1982) (subdivision (1) of "work-made-for-hire" definition).

${ }^{70} I d$. (subdivision (2) of "work-made-for-hire" definition).

71 See Angel \& Tannenbaum, supra note 43, at 230; see also id. at 236 ("[The 1976 Act] does not reflect the holding of [decisions such as Brattleboro Publishing Co. v. Winmill Publishing Corp., 369 F.2d 565 (2d Cir. 1966) (discussed supra notes 23$25)$ ], but instead wisely provides that only the specified works on commission may be considered works made for hire, and then only by observing the prescribed formalities.").

72 H.R. ReP. No. 1476, 94th Cong., 2d Sess. 121, reprinted in 1976 U.S. Code Cong. \& ADMIN. News 5659, 5736.

73 Ringer, supra note 3 , at 188. 
law, the failure to explicitly incorporate prior case law is telling. Where the 1976 Act incorporated prior case law, such was made clear in the legislative history, for example: "There is no need for a specific statutory provision concerning the rights and duties of the co-owners of a work; court-made law on this point is left undisturbed."74 Because there was no explicit incorporation of prior case law concerning works made for hire, the 1976 Act provided the basis for completely new judicial treatment of commissioned works made for hire.

\section{Works MAde for Hire UNDER THE 1976 ACT}

The 1976 Act defines a "work made for hire" in section 101 as:

(1) a work prepared by an employee within the scope of his or her employment; or

(2) a work specially ordered or commissioned for use

as a contribution to a collective work,

as a part of a motion picture or other audiovisual work,

as a translation,

as a supplementary work,

as a compilation,

as an instructional text,

as a test,

as answer material for a test,

or as an atlas,

if the parties expressly agree in a written instrument signed by them that the work shall be considered a work made for hire. ${ }^{75}$

Section 201 defines ownership of copyright and explains how works made for hire fit into the statutory scheme:

(a) Initial Ownership-Copyright in a work protected under this title vests initially in the author or authors of the work .... .

(b) Works Made for Hire-In the case of a work made for hire, the employer or other person for whom the work

74 H.R. REP. No. 1476, supra note 72.

75 17 U.S.C. $\S 101$ (1982) (emphasis added). For the purposes of this Comment, the first subdivision of the work-made-for-hire definition in $\$ 101$ is designated "subdivision (1)" and the second subdivision is designated "subdivision (2)."

The term "collective work" includes magazines and newspapers, and thus subdivision (2) potentially affects a large number of artists and authors. See 1 M. Nimmer, supra note 21 , at $\S 3.02$, at $3-5$ to -8 . 
was prepared is considered the author for purposes of this title, and, unless the parties have expressly agreed otherwise in a written instrument signed by them, owns all of the rights comprised in the copyright. ${ }^{76}$

Subdivision (1) provides the exclusive definition for works made for hire created by employees. So long as the creation falls within the employee's "scope of employment," the work is automatically a work made for hire. ${ }^{77}$ Pursuant to section 201, therefore, the employer becomes the author of the work and retains the copyright.

It would also appear from both the legislative history ${ }^{78}$ and the structure of the section itself that subdivision (2) is the exclusive category for works created on commission by independent contractors. ${ }^{78}$ Subdivision (2) provides that works commissioned by a contracting party can be considered works made for hire only if the works fall into one of the specified categories and the parties have signed a contract expressly designating the work as a work made for hire. ${ }^{80}$ The initial interpretations of the 1976 Act's work-made-for-hire provisions confirmed this reading of subdivision (2), holding that, absent satisfaction of both of the statutory prerequisites, a commissioned work was not a work made for hire, thereby allowing independent artists to retain the copyright in their works. ${ }^{81}$ Beginning with the 1984 decision in Aldon Accessories Ltd. v. Spiegel Inc., ${ }^{82}$ however, the Second and Seventh Circuits have embarked on a line of reasoning that threatens to undermine the legislative compromise represented by the 1976 Act's workmade-for-hire provisions.

7617 U.S.C. § 201 (1982).

7717 U.S.C. $\S 101(1)$ (1982). See also Note, The Works Made for Hire Doctrine Under the Copyright Act of 1976 - a Misinterpretation: Aldon Accessories Ltd. v. Spiegel Inc., 20 U.S.F. L. REV. 649, 655-56 (1986) (describing the 1976 Act's workmade-for-hire provisions).

${ }^{78}$ See supra notes 45-67 and accompanying text (describing process of revision of the Copyright Act).

${ }_{79}$ See Gallay, Authorship and Copyright of "Works Made for Hire": Bugs in the Statutory System, 8 ART \& L. 573, 579 (1984) (maintaining that $\$ 201$ (b) language "or other person for whom the work is prepared" indicates congressional intent to treat employees and independent contractors separately); Kadden, Recent Judicial Developments in the Copyright Law of the United States of America, 16 COPYRIGHT 217, 22223 (1980) ("[T]he 1976 Act's definition of a 'work made for hire' distinguishes sharply between works prepared by an employee within the scope of his employment and works specially ordered or commissioned.").

so 17 U.S.C. \& 101(2) (1982).

81 See infra notes 83-94 and accompanying text (discussing cases). See also $1 \mathrm{M}$. NIMMER, supra note 21 , at $\S 5.03(\mathrm{~B})(2)$, at 5-19 to -21 (1986); Angel \& Tannenbaum, supra note 43, at 232 (discussing the 1976 Act's treatment of commissioned works).

B2 738 F.2d 548 (2d Cir.), cert. denied, 469 U.S. 982 (1984). 


\section{A. Judicial Interpretation of the 1976 Provisions}

The early cases applying the 1976 Act to works prepared by independent contractors read subdivision (2) as the exclusive provision governing commissioned works. For example, the court in Meltzer $v$. Zoller $^{83}$ construed the 1976 commissioned work-made-for-hire provisions as excluding the architectural drawings in question from workmade-for-hire status. ${ }^{84}$ In Meltzer, a homeowner claimed authorship in the architectural plans of his home. The court found that the homeowner could not claim copyright in the plans, which were derived from stock drawings and his suggestions, because they were not works made for hire. The court excluded the plans from the work-made-for-hire doctrine, because architectural plans do not fall into one of the enumerated categories in section 101 and there was not the required express written agreement between the homeowner and the architect denoting the architectural plans as works made for hire. ${ }^{\mathbf{8 5}}$

8s 520 F. Supp. 847 (D.N.J. 1981).

84 The court's holding in Meltzer was in some ways foreshadowed by the decision in May v. Morganelli-Heumann \& Assoc., 618 F.2d 1363 (9th Cir. 1980), in which the Ninth Circuit, while deciding the case under the 1909 Act, indicated in dicta that, under the 1976 Act, the architectural drawings in question "would not be subject to the 'works for hire' doctrine, both because of the absence of a written agreement so providing, and because the drawings do not fall within one of the prescribed categories of work." May, 618 F.2d at 1368 n.4. See also Evert v. Arkham House Publishers, Inc., 579 F. Supp. 145 (W.D. Wis. 1984) (1909 Act applicable, but "if the 1976 statute was applicable, the admitted lack of a written agreement between the parties and the type of work involved here (a book of poetry . . .) would summarily dispose of [the publisher's] work-for-hire argument").

${ }^{85}$ Meltzer, $520 \mathrm{~F}$. Supp. at 855 . The court explained its method of construction:

As a rule, "[a statutory] definition which declares what a term "means" . . . excludes any meaning that is not stated.' . . In this regard, it is a well-known canon of construction that the language of the statute is the best indication of legislative intent. Architectural drawings are not included in the categories set forth in Section 101; and hence in accordance with the above-stated principles, do not qualify as works made for hire ... This is true even though the 1909 Act and certain common law jurisdictions included architectural drawings within the rubric of works made for hire, for it may be presumed that Congress was aware of the prior construction of the terms in the original act, and deliberately limited the scope of the new Act....

Id. (citations omitted). The most recent case recognizing Congress's intended dichotomy between employee works and commissioned works is Easter Seal Soc'y for Crippled Children \& Adults, Inc. v. Playboy Enter., No. 85-3741 (5th Cir. April 23, 1987) (LEXIS, Genfed library, Dist file) ("read \& 101 as a reflection of a simple dichotomy in fact between employees and independent contractors"); see also Whelan Assoc. v. Jaslow Dental Laboratory, 609 F. Supp. 1307, 1319 (D.C. Pa. 1985) ("Under the 1976 Copyright Act the works for hire doctrine only applies to independent contractors in certain limited circumstances defined by the Act."); Childers v. High Soc'y Magazine, Inc., 557 F. Supp. 978, 984 (S.D.N.Y. 1983) (holding that a commissioned work cannot be a work made for hire in the absence of a written agreement designating it as 
The same reasoning was followed in Mister $B$ Textiles, Inc. $v$. Woodcrest Fabrics, Inc. ${ }^{88}$ In Mister $B$ Textiles, the plaintiff sued for copyright infringement of a fabric design. The plaintiff firm hired a design company to create a new design for the firm's use. Thereafter, plaintiff became aware of the defendant's alleged infringement of the rights to the design. The plaintiff argued it held the copyright to the design and, therefore, should prevail on the infringement claim, because the design was a work for hire. The defendant responded that the design could not be a work made for hire, because fabric design was not one of the enumerated categories of commissioned works eligible to be works made for hire. ${ }^{87}$ The court agreed with the defendant's interpretation of the 1976 Act, $^{88}$ but granted the plaintiff's claim to coyright on joint copyright grounds. Because the plaintiff's employee had significantly contributed to the creation of the design, she became one of the joint owners of the work. ${ }^{89}$ As an employee of the plaintiff, her rights in the copyright passed to the plaintiff under the work-made-for-hire provision regarding employees in subdivision (1). ${ }^{90}$

The reasoning employed by the courts in Meltzer and Mister B Textiles to interpret the work-made-for-hire provisions of the 1976 Act provided no surprises. It was consonant with the legislative history of the Act and its language. ${ }^{91}$ Two authors writing in 1976 were so confident in the clarity of the language and the legislative history of section

such); Aitken, Hazen, Hoffman, Miller, P.C. v. Empire Const. Co., 542 F. Supp. 252 , 257 (D. Neb. 1982) (holding that $\S 101$ limits commissioned works made for hire to specific categories and those instances where there is an express agreement in writing).

${ }^{86} 523$ F. Supp. 21 (S.D.N.Y. 1981).

87 Id. at 24 .

88 Id.

so Id. at 24-25 ("[C]oowners of a copyright would be treated generally as tenants in common, with each coowner having an independent right to use or license the work ....") (quoting H.R. REP. No. 1476, supra note 72); see also 17 U.S.C. § 201(a) (1982) ("The authors of a joint work are coowners of copyright in the work.").

${ }^{90}$ Mister B Textiles, 523 F. Supp. at 25. Section 201 provides in part:

In the case of a work made for hire, the employer or other person for whom the work was prepared is considered the author for purposes of this title, and, unless the parties have expressly agreed otherwise in a written instrument signed by them, owns all of the rights comprised in the copyright.

17 U.S.C. § 201(b) (1982).

${ }^{21}$ See Angel \& Tannenbaum, supra note 43, at 231-32 (discussing the 1964 and 1965 proposed revisions in which the definitional structure of 'works made for hire' that ultimately became $\S 101$ was formulated); see also Oddo v. Ries, 743 F.2d 630, 634 (9th Cir. 1984) (refusing to find that a series of articles revised for inclusion in a collective work constituted work made for hire because the parties did not expressly agree in a written statement that the work was to be a work made for hire). 
101 that they stated:

Section $101 \ldots$ wisely defines which works on commission may be considered works for hire . . . [T] [Te new definitions of works made for hire in sections 101 and 201 (b) will do much to narrow the possible areas of dispute and provide guidelines which will enable third parties to more easily ascertain who owns the rights in a given work for hire or work on commission. ${ }^{92}$

In 1984, however, the Court of Appeals for the Second Circuit decided a case that turned section 101 on its head. The court's interpretation of section 101 in Aldon Accessories Ltd. v. Spiegel, Inc., ${ }^{93}$ enlarged the possible areas of dispute and made it much more difficult for any party to be certain whether a particular work is a work made for hire.

\section{B. Aldon Accessories and its Progeny}

1. The Aldon Acessories Decision

The reasoning in Aldon Accessories is problematic for independent contractors who could, as a result of the court's opinion, have their creations unwittingly classified as works made for hire, but the decision is very much a product of the particular facts in that case. Aldon Accessories Ltd. ("Aldon") designs and markets figurines and other decorative pieces. One of its two principals, Arthur Ginsberg, in 1977 conceived of a line of statuettes of mythical creatures, most notably a unicorn and a Pegasus. After first working with a Japanese firm to develop porcelain models of the statuettes, ${ }^{94}$ Ginsberg later conceived the idea of marketing similar unicorns in brass and contacted a Taiwanese firm to develop them. In the same way he had worked with the Japanese artists, he worked with the Taiwanese artists to create brass models of the unicorn. He filed a certificate of copyright registration for the brass unicorns, also designating Aldon as the author and the works as works made for hire. ${ }^{95}$

92 Angel \& Tannenbaum, supra note 43, at 239.

os 738 F.2d 548 (2d Cir.), cert. denied, 469 U.S. 982 (1984). The Second Circuit has been referred to as the "de facto Copyright Court of the United States." Easter Seals Soc'y for Crippled Children \& Adults, Inc. v. Playboy Enter., No. 85-3741 (5th Cir. Apr. 23, 1987) (LEXIS, Genfed library, Dist file).

94 Id. at 549-50. At trial, Ginsberg testified that the artists, working under his direct supervision, "spent hours and hours changing shapes, adjusting attitudes and proportions until finally I thought there was a model that I liked." Id. at 550.

${ }^{85}$ Id. at 550. 
Aldon advertised the brass unicorns and exhibited them at the Chicago Gift Show in 1981. A buyer for Spiegel, Inc. ("Spiegel") examined the brass unicorn line for a half hour, after which the buyer requested samples and took a catalog. The samples were sent. By mid1981, through its catalog, Spiegel was selling brass unicorns identical to Aldon's statuette. Aldon sued Spiegel for copyright infringement. ${ }^{96}$

The primary factual dispute in Aldon Accessories centered on the nature of the relationship between Aldon and the Taiwanese firm that had developed Aldon's brass unicorns. ${ }^{97}$ To resolve this issue, the trial court explored the nature and extent of Ginsberg's supervision, on behalf of Aldon, of the Taiwanese firm. ${ }^{88}$ In his instructions to the jury, concerning Aldon's claim that the statuettes were works made for hire, the trial judge gave the following charge:

A work for hire is a work prepared by what the law calls an employee working within the scope of his employment. What that means is, a person acting under the direction and supervision of the hiring author, at the hiring author's instance and expense. It does not matter whether the for-hire creator is an employee in the sense of having a regular job with the hiring author. What matters is whether the hiring author caused the work to be made and exercised the right to direct and supervise the creation. ${ }^{99}$

The jury found that Spiegel had violated Aldon's copyright and awarded more than $\$ 100,000$ damages to Aldon. ${ }^{100}$

On appeal, Spiegel asserted that the jury instruction was clearly erroneous, arguing that the jury charge, which predicated work-madefor-hire status on the direction and supervision of the contractor, was a restatement of the law under the 1909 Act, and was not an accurate statement of the present state of the law. Under the 1976 Act, Spiegel argued, the statuettes could not be works made for hire, because statuary does not fall into one of the explicit categories listed in section 101 and because the parties signed no express written agreement designating the statuettes as works made for hire. ${ }^{101}$

${ }^{28} I d$.

97 Spiegel also contended in its defense that it had ordered its brass unicorns from Taiwan before its buyer saw those of Aldon at the trade show. This factual issue was resolved in Aldon's favor at trial. Id. at 551.

88 At trial, Ginsberg testified that the process through which the brass unicorns was created was substantially similar to that followed in the production of the porcelain unicorns. See supra note 94.

92 Aldon Accesories, 738 F.2d at 551.

100 Id. at 549.

101 Id. at 551. 
In his opinion in Aldon Accessories, Judge Feinberg responded that Spiegel was correct in its assertion that the statuettes could not be works made for hire under subdivision (2) of the 1976 Act, but observed that Spiegel gave an overly restrictive interpretation of subdivision (1), which governs works prepared by an employee within the scope of her employment. ${ }^{102}$ Judge Feinberg asserted that both subdivision (1) and subdivision (2) applied to independent contractors, but subdivision (2) was drafted only for those instances "where the contracting party did all of the creative work and the hiring party did little or nothing." ${ }^{103}$ Thus, subdivision (2) presented a special subcategory of the general category of independent contractors. Under this reading of the statute, the Taiwanese firm, acting under the instructions of Ginsberg, could be considered an employee of Aldon, with the result that the statuettes in question were works made for hire under subdivision (1). The court based its argument almost entirely on legislative silence:

Nothing in the 1976 Act or its legislative history indicates that Congress intended to dispense with this prior law .... Had Congress intended . . . to narrow the type of employment relationships within the work for hire doctrine to include only "regular" employees, it is unlikely that there would have been no discussion of this change .... .

... But there is no indication in the legislative history or elsewhere that Congress was focusing on contractors who were actually sufficiently supervised and directed by the hiring party $\ldots .^{104}$

In an attempt to give some independent significance to the specific commissioned works provisions of subdivision (2), the court made its only explicit reference to the 1976 Act's legislative history. Acknowledging that Congress ințended to change prior work-made-for-hire law relating to commissioned works, the court stated that the law under the 1909 Act was unsatisfactory, because it "frequently worked an injustice in those situations where the contractor did all of the creative work and the hiring party did little or nothing." 105 The court asserted that subdivision (2) was intended to correct "those situations."

Judge Feinberg's interpretation of the legislative history of the 1976 commissioned works provisions is highly dubious. To argue that congressional silence entails the inclusion of prior law is compelling

102 Id. at 551-52.

10 Id. at 552.

104 Id.

105 Id. 
when the statute under consideration is one that merely revised or codified prior law. ${ }^{108}$ In the circumstances of the complete overhaul of the copyright law found in the 1976 Act, however, that argument from silence is much less convincing. ${ }^{107}$ Furthermore, to argue that subdivision (2) covers only a subcategory of all possible independent contractors is to ignore the legislative development of that clause. The preliminary draft of the 1976 Act excluded all independent contractors from operation of the work-made-for-hire rules. ${ }^{108}$ Only after debate and compromise were certain, specific types of independent contractors included in the legislation. ${ }^{109}$

Ironically, the one legislative source that is cited in Aldon Accessories contains language that refutes Judge Feinberg's argument. Describing the commissioned-works provision in what became the 1976 Act, the House Report cited in Aldon Accessories commented: "The definition now provided by the bill represents a compromise which, in effect, spells out those specific categories of commissioned works that can be considered 'works made for hire' under certain circumstances."110 Neither the history of the evolution of the 1976 commissioned work-made-for-hire clause nor the House Report to which the court referred justified the court's assumption that subdivision (1) could encompass all commissioned works made for hire except those listed in subdivision (2).

It should be noted that Judge Feinberg found himself in a difficult situation in Aldon Accessories. It had already been resolved at trial that Spiegel did in fact copy Aldon's Taiwanese unicorns. ${ }^{111}$ Owing to deficiencies in Taiwanese copyright law, however, Aldon was the only party in a position to challenge Spiegel's behavior. ${ }^{112}$ Furthermore, it

106 1A N. Singer, STAtutes AND STATUtory Construction $\S 22.27$, at 25455 (rev. ed. 1985).

${ }_{107}$ See supra notes $72-74$ and accompanying text.

108 See supra note 56 and accompanying text.

109 See supra notes 65-67 and accompanying text (describing formulation of the 1976 Act's commissioned works provisions).

110 See H.R. REP. No. 1476, 94th Cong., 2d Sess. 121, reprinted in, 1976 U.S. Code Cong. \& Admin. News 5659, 5737.

111 Aldon Accessories, 738 F.2d at 549.

112 While the reasoning adopted by Judge Feinberg had in fact been advanced previously, see O'Meara, "Works Made for Hire" Under the Copyright Act of 1976-Two Interpretations, 15 CREIGHTON L. REv. 523 (1982), it has been suggested that Judge Feinberg's opinion was also motivated by practical considerations. See Goldberg \& Ginsburg, Judicial Developments in the United States Copyright Law, 123 Revue Internationale du Droit d'Auteur 3, 33 (1985) ("Because many of the Far Eastern countries in which American companies commission the creation of dolls, toys, decorative artworks, and similar works . . . are neither signatories to a bilateral copyright treaty with the U.S., nor to a multilateral copyright treaty to which the U.S. is a party, the resulting works, if published, will not be protected in the U.S. 
was clear that the brass unicorns could not be considered works made for hire under subdivision (2). Therefore, although the equities of the case tipped in favor of Aldon, the court was forced to search for a legal ground to hold in Aldon's favor.

The court met this difficulty by interpreting subdivision (1) in a manner that, contrary to the language and legislative history of the statute, allowed independent contractors to be considered employees for the purpose of work-made-for-hire analysis. Although he reached an equitable result, Judge Feinberg overlooked a manner of resolving the case in Aldon's favor on less strained statutory grounds. Based on the findings of the trial court, Ginsberg played a very active role in the development of the brass unicorns. ${ }^{113}$ If so, a strong argument could be made that Ginsberg was a joint owner of the copyright. ${ }^{114}$ Since Ginsberg was a principal/employee of Aldon, and developing the statuettes was within the scope of his duties, ${ }^{115}$ his joint ownership rights in the statuettes should have passed to Aldon under subdivision (1), thus allowing Aldon to maintain its suit against Spiegel. ${ }^{118}$ This resolution of the case would be in accord with the reasoning in Mister B Textiles $v$. Woodcrest Fabrics, ${ }^{117}$ where the court found that if the employee of a company contributed significantly to the creation of the work, then the company was joint owner of the copyright under subdivision (1). ${ }^{\mathbf{1 1 8}}$

unless the commissioning company is deemed the 'author', [sic] or unless the works are first publicly distributed in the U.S. or in a treaty country."); $c f$. Cooling Systems and Flexibles, Inc. v. Stuart Radiator, Inc., 777 F.2d 485, 489 (9th Cir. 1985) (holding that the nationality of work made for hire of nondramatic literary material produced by non-domiciliary resides in employer).

113 See supra note 94 and accompanying text. There is reason to believe, however, that Ginsberg's input was not as extensive as one might think from reading the circuit court's opinion. See FitzGibbon \& Kendall, The Unicorn in the Courtroom: The Concept of "Supervising and Directing" an Artistic Creation is a Mythical Beast in the Copyright Law, 15 J. ARTs MGMT. \& L. 23, 27-29 (1985) (counsel for Spiegel suggesting that Ginsberg's creative input and supervision were minimal).

${ }_{114}$ It is possible that the Aldon Accessories court did not decide the case on joint authorship grounds because it was uncertain whether the record warranted a finding that Ginsberg was in fact a joint author. See supra note 113. However, it seems more likely that the court, by adopting reasoning similar to that of Justice Friendly in his dissent in Scherr, see supra notes 35-38 and accompanying text, lost sight of the distinction between work-made-for-hire and joint ownership analysis. The court's misinterpretation of the legislative history of subdivision (2) also involved a blurring of the line between joint ownership and work made for hire. See supra note 105 and accompanying text.

115 See 17 U.S.C. $\$ 101$ (1982). Ginsberg was in charge of the production and creative aspects of the business. Aldon Accessories, 738 F.2d at 549.

118 See Certiorari Brief for Petitioners at 14, Aldon Accessories Ltd. v. Spiegel, Inc., 469 U.S. 982 (1984) (denying certiorari) (arguing that correct result of Aldon Accessories would have been finding that Ginsberg was a joint author).

117523 F. Supp. 21 (S.D.N.Y. 1981).

118 Id. at 24-25. One difficulty for the artist in making the commissioning party 
Standing alone, Aldon Accessories could be dismissed as an example of an appellate court reaching an equitable result by the easiest available reasoning, and its potential to upset the legislative compromise concerning commissioned works could be ignored. Unfortunately, if the recent Seventh Gircuit opinion in Evans Newton Inc. v. Chicago Systems Software ${ }^{110}$ is any indication, the reasoning in Aldon Accessories is developing a life of its own independent of the peculiar facts that gave rise to the Second Circuit's decision.

\section{Evans Newton Inc. v. Chicago Systems Software}

In Evans Newton, the plaintiff, Evans Newton Incorporated ("ENI") was a corporation providing recordkeeping systems to schools. In 1979, ENI decided to develop management software, and entered into an agreement with Chicago Systems Software ("CSS") to develop the programming. Following CSS's demonstration of the program, CSS's president signed an "ENI Microcomputer Program Copyright Statement," which stated that CSS recognized ENI's "exclusive property" rights in the program and that CSS "agree[d] not to sell, trade, give, or intentionally make available programs written for ENI. . . ."120 Subsequent to the signing of this agreement, however, CSS began to market a competing program and user's manual, which were materially similar to the program it had prepared for ENI. The district court found that CSS's program was a work made for hire and that CSS was guilty of copyright infringement, levying an injunction and assessing damages. ${ }^{121}$

On appeal, CSS argued that its work could not be a work made for hire under the 1976 Act, because no signed, written agreement

joint owner with the artist lies in the fact that the artist then could not terminate the commissioner's ownership. However, the joint owner does have the right to his share of the profits, so that joint ownership is better economically than work-made-for-hire status. See Jerry Vogel Music Co. v. Miller Music, Inc., 272 A.D. 571, 574-75, 74 N.Y.S.2d 425, 427-28 (1947), affd, 299 N.Y. 782 (1949) (co-owners of joint copyright are accountable to each other).

There are two other ways one might think of the Aldon facts. First, one might argue that Ginsberg/Aldon were sole authors of the piece in the same way a poet is author of a poem that she dictates to a stenographer. Second, one could argue that the brass works were derivative of the porcelain works made with the Japanese artists in 1977. Since the 1976 Act did not go into effect until 1978, the decision would have been decided under the 1909 Act, assuming that United States law would have been applicable rather than Japanese. Under the later interpretation of the 1909 Act, the Japanese artists would have created works made for hire and Aldon would have been the author of the original and the derivative works.

119793 F.2d 889 (7th Cir.), cert. denied, 107 S. C.t 434 (1986).

120 Id. at 892 n.3.

121 Id. at 893. 
designating the program as a work made for hire existed and because computer programs did not fall under the enumerated categories in subdivision (2). GSS claimed, instead, that it was a co-owner with ENI. ${ }^{122}$ Furthermore, it argued that since the district court had found that CSS was an "independent contractor" and thus outside the scope of subdivision (2), its work could not be a work made for hire.

Relying on Aldon Accessories, Judge Harlington Wood rejected CSS's framing of the issue:

[T] $\mathrm{T}$ he proper issue was not . . . whether the defendant was an employee or an independent contractor, but rather "[was] the contractor "independent" or [was] the contractor so controlled and supervised in the creation of the particular work by the employing party that an employer-employee relationship exist[ed]. ${ }^{123}$

The court followed the Aldon Accessories decision, because it believed that the Aldon Accessories court "carefully considered the legislative history of 17 U.S.C. $\S 101 . " 124$ As has already been asserted, this assumption is highly questionable. ${ }^{125}$ While, as in Aldon Accessories, Evans Newton involved an appellate court affirmance of a decision that could be supported on other grounds, ${ }^{126}$ the ease with which the reasoning in Aldon Accessories was accepted is troubling.

\section{Consequences of the Adoption of the Aldon Accessories Reasoning}

What is the likely result of widespread use of the Aldon Accessories court's reasoning in work-made-for-hire cases? As Evans Newton suggests, such reasoning leaves the door open for hiring parties, who have failed to get a full assignment of copyright rights from independent contractors falling outside the subdivision (2) guidelines, to unilaterally obtain work-made-for-hire rights years after the work has been completed as long as they directed or supervised the work, a standard that is hard not to meet when one is a hiring party. Not only would

122 Id.

123 Id. at 894 (quoting Aldon Accessories, 738 F.2d at 552); see also Marshall v. Miles Laboratories, Inc., 647 F. Supp. 1326, 1331 (N.D. Ind. 1986) ("critical question was whether the employer caused the work to be made and exercised the right to direct and supervise the creation").

124 Evans Newton, 793 F. 2d at 894.

125 See supra notes $106-10$ and accompanying text.

${ }^{128}$ Evans Newton, 793 F.2d at 893 n.4 (holding in the alternative that CSS's marketing of its materially similar program could be enjoined on the grounds that CSS had breached its confidentiality agreement with ENI). 
adopting such a standard frustrate the intent of the drafters of the 1976 Act that certain independent contractors never fall under the workmade-for-hire doctrine $\mathrm{e}^{\mathbf{1 2 7}}$ and should retain their copyright rights unless and until they had assigned such rights to third parties, but it also would remove the certainty with which all parties could know the status of a work created by an independent contractor under the 1976 Act. The Aldon Accessories reasoning in effect puts the independent contractor in nearly as bad a position as she was under the pre-1976 law when her works were presumed to be works made for hire. She can never be certain whether she will continue to be able to maintain her copyright rights. ${ }^{128}$ Furthermore, since her rights in the artwork are not definitely hers, she is likely to receive less if she tries to alienate those rights than she would have received had she had absolute rights in the work.

Moreover, since the focus of the inquiry has shifted from whether an artist is classified as an independent contractor or an employee to the issue of whether the employer has a right to supervise, theoretically, a court could apply subdivision (1) to those types of contractors specifically enumerated in subdivision (2), thereby gutting the requirement of a written, signed agreement designating those types of independent contractors' works as works made for hire. Taken to its logical conclusion, application of the Aldon Accessories adoption of the Scherr majority's right to supervision test ${ }^{129}$ erases twenty years of carefully crafted compromises. Subdivision (2) becomes superfluous and many more works become works made for hire than Congress intended.

127 See supra notes 65-67 and accompanying text.

${ }^{128}$ This loss in certainty is even more pronounced once one examines the decisions applying the Aldon Accessories reasoning and supervision test. See Iris Arc v. S.S. Sarna, Inc., 621 F. Supp. 916, 919-20 (E.D.N.Y. 1985) (holding that the fact design had to meet with hiring party's approval is sufficient to designate the design as a work made for hire under subdivision (1)); Sygma Photo News, Inc. v. Globe Int'l, Inc., 616 F. Supp. 1153, 1156 (S.D.N.Y. 1985) (holding that photographer's deference to royal family does not render photographs works made for hire).

One district court decision decided before Aldon Accessories also implicitly followed the same reasoning. Town of Clarkstown v. Reeder, 566 F. Supp. 137, 141 (S.D.N.Y. 1983) (without reference to $\S 101$ provisions, "parties agree that resolution of the issue of Clarkstown's supervision and control over the Manual is tantamount to a ruling on the preliminary injunction"); see also Sykee v. Roulo, 122 Ill. App. 3d 331, 334, 461 N.E.2d 480, 483 (1984) ("crucial question is if plaintiff had the right to control the work").

${ }^{120}$ See supra note 33 and accompanying text (discussing the majority opinion in Scherr v. Universal Match Corp., 417 F.2d 497 (2d Cir. 1969), cert. denied, 397 U.S. $936(1970))$. For an example of a court taking the right to supervision test to its extreme, see CCNV v. Reid, 652 F. Supp. 1453, 1456 (D.D.C. 1987) ("If the putative 'employee' . . . possessed the right to 'direct and supervise' the manner in which the work was done, the copyright is his no matter the degree of creative license actually exercised by the artist-employee."). 
The Aldon Accessories reasoning could also open another Pandora's box. In addition to discussing the hiring party's right to supervise, the court emphasized the amount of supervision and direction Ginsberg supplied, echoing Judge Friendly's criterion for works made for hire in his Scherr dissent. The court stated that Ginsberg "was, in a very real sense, the artistic creator."130 If the standard under subdivision (1) is whether the employer made a significant artistic contribution, then many employee works could not be works made for hire and the majority of commissioned works would not be works made for hire. Thus, many fewer works could be designated as works made for hire than Congress intended. Hence, if the Aldon Accessories decision is understood as the an example of the doctrine asserted by Judge Friendly, all work-made-for-hire issues could become issues of joint ownership and relative rights, and both subdivisions (1) and (2) would become superfluous. Whether courts interpret the supervision test in Aldon Accessories as that introduced by the majority or the dissent in Scherr, the result misses the mark intended to be reached by Congress.

\section{The 1976 Work-Made-For-Hire Provisions Are IN NEED OF REFORM}

The deleterious consequences of widespread application of the $\mathrm{Al}$ don Accessories reasoning cannot be fully appreciated without some insight into the practical operation of the 1976 Act's work-made-for-hire provisions. Aldon Accessories makes it possible for commissioned works to be classified as employee works made for hire; the decade of experience under the 1976 Act has demonstrated two other unfortunate trends. The first is that almost any work capable of contractual categorization as a work made for hire will in fact become a work made for hire. The second is that, under the 1976 Act, the author of a work made for hire is almost certain to be undercompensated for the full value of her work, owing to the artists' inferior bargaining power. This part of the Comment explores the deficiencies of the 1976 Act's workmade-for-hire provisions and suggests amendments that will restore the Act's originally intended balance between the interests of the creators and the purchasers of commissioned works.

\section{A. The Current Commissioned Work-Made-for-Hire Provisions Fail to Promote the Policies of Copyright Law}

The policies intended to be furthered by the revision of copyright 
law can best be described by two passages from one of the early reports on the revision:

While some limitations and conditions on copyright are essential in the public interest, they should not be so burdensome and strict as to deprive authors of their just reward. ... [T] fair share of the revenue to be derived from the market for their works.

The primary purpose of copyright is to stimulate the creation and dissemination of intellectual works, thus advancing "the progress of science and useful arts." The grant of exclusive rights of authors is a means of achieving this end, and of compensating authors for their labors and their contributions to society. ${ }^{131}$

Thus, the 1976 Act was intended to accomplish three goals: the stimulation of creation, the dissemination of creative works, and the fair compensation of authors for their contributions. The operation of the Act's commissioned work-made-for-hire clauses has established an impediment to all three goals.

Senator Thad Cochran of Mississippi has proposed legislative amendments to the 1976 Act's work-made-for-hire provisions in $1982,{ }^{132} 1983,{ }^{133}$ and $1986{ }^{134}$ Only the 1982 bill made it far enough to merit hearings before the Committee on the Judiciary; ${ }^{136}$ those hearings are very instructive of how the 1976 Act was working after four years in operation.

Senate Bill 2044, introduced in 1982, sought to eliminate the fol-

131 Register of Copyrights, supra note 9, at 6.

132 S. 2044, 97th Cong., 2d Sess., 128 ConG. Rec. 649 (1982).

133 S. 2138, 98th Cong., 1st Sess. (1983). The proposal was also submitted in the House by Rep. Barney Frank. H.R. 5911, 98th Cong., 2d Sess. (1984).

${ }_{134}$ S. 2330 , 99th Cong., 2d Sess., 132 Cong. Rec. S4494 (daily ed. Apr. 17, 1986). Senator Cochran intends to file legislation similar to S. 2330 in 1987. Telephone interview with Ms. Linda Slade, Legislative Assistant to U.S. Senator Thad Cochran (March 31, 1986).

${ }^{195}$ Definition of Work Made for Hire in the Copyright Act of 1976: Hearing on S. 2044 Before the Committee on the Judiciary, 97th Cong., 2d Sess. (1982) [hereinafter Hearing]. In 1986, the Senate Judiciary Committee did not hear S. 2330 and thus the bill died in committee in part because the Judiciary Committee was conducting impeachment hearings regarding Judge Harry E. Glaiborne, and tax reform was at a fever pitch. Telephone interview with Ms. Linda Slade, Legislative Assistant to Senator Thad Cochran (January 29, 1987). In such an atmosphere, copyright revision becomes relegated to being an "after dinner mint" on the "banquet table" of legislation. Telephone interview with Ms. Margi Trapani, Graphic Artists Guild (Jan. 29, 1987) (quoting discussion between Graphic Artists Guild representatives and legislative aide). 
lowing categories from the list of types of commissioned works found in subdivision (2): contributions to collective works, works part of motion pictures and other audiovisual works, and instructional texts. ${ }^{136}$ Exclusion of the category of contributions to collective works potentially affected both publishers and anyone who submitted work to magazines, including writers, photographers, and graphic artists. Those groups provided the bulk of the testimony.

During the 1982 hearings on Senate bill 2044, The Association of American Publishers stated most succinctly the view all the other publishers' groups espoused, that the 1976 Act's provisions for commissioned works made for hire were a "balanced, workable, and fair resolution" in no need of revision. ${ }^{137}$ This was the compromise for which they had hoped. The Magazine Publishers Association went so far as to say that the 1976 "statutory provisions for work made for hire . . . are incapable of becoming a mechanism for oppressing individual contributors." ${ }^{238}$ The stories told by the authors and other artists testifying indicated otherwise.

\section{Fair Compensation for Artists}

Just as the artists had feared in debates over the drafting of the 1976 Act, ${ }^{139}$ the requirement of a written contract merely opened the way for the exploitation of their works. Due to the parties' unequal bargaining power, ${ }^{140}$ when writing for publishing houses, authors frequently found themselves in the position of having only two choices: either submit work as work made for hire or do not submit work at

${ }^{136}$ See S. 2044, supra note 132, at 292.

${ }^{137}$ Hearing, supra note 135, at 71 (statement of the Ass'n of American Publishers). Even though artists were complaining bitterly about the operation of the 1976 work-made-for-hire provisions, publishers argued that they deserved the authorial status granted by work-made-for-hire contracts, because they made substantial investment of time, skills, and money in the works. Id. at 70-71.

198 Id. at 58 (statement of Mr. E. Gabriel Perle on behalf of the Magazine Publishers Ass'n).

139 See supra note 60 and accompanying text.

140 See Note, Blanket Licensing: A Proposal for the Protection and Encouragement of Artistic Endeavor, 83 Colum. L. REv. 1245, 1254 n.57 (1983) ("An artist's total dependence on the publisher to reach the public explains [the leverage a publisher has over an artist]."). One commentator has responded to the unequal bargaining power between contracting parties and independent contractors by arguing that "[f]reelance authors ... ought to lose their fictitious status as entrepreneurs and should come to be viewed, for purposes of social insurance, tax and antitrust law in particular, as that which they really are, the quasi-employees of quasi-employers, usually the media." Cohen Jehoram, The Author's Place in Society and Legal Relations Between Authors and Those Responsible for Distributing Their Works, 14 CoPYRIGHT 385, 385 (1978). 
all. ${ }^{141}$ As a result, work-made-for-hire clauses have become the norm in magazine publishing contracts. ${ }^{142}$ During the hearings on Senate bill 2044, the Magazine Publishers Association denied that authors were in weaker bargaining positions than publishers. The Association argued that "the writers assigned or commissioned to write articles for recognized magazines are almost invariably part of a comparatively small group of well-known freelancers who have and exercise bargaining power on an equal level with that of the editor or publisher."143 The Association's reservation of equal bargaining power to the well-known artists is telling, since it amounts to an admission that less well-known artists are indeed at the mercy of the publisher. In addition, there is reason to believe that the Association's characterization of the bargaining power of established free-lance artists was less than forthright. As one graphic artist, who frequently prepares illustrations for major publishing houses, noted: "The great majority of artists are not stars. The fact that James Michener can negotiate any contract that he wants is not only debatable but also irrelevant to the problems faced by professionals at all levels." ${ }^{144}$ Elmer Bernstein, representing the Screen Composers of America, also refuted the notion that work-made-for-hire abuses were only relevant to the unknown or beginning author. $\mathrm{Mr}$. Bernstein testified that he is "considered to be probably one of the top composers in [his] field" and that he "command[s] probably the highest fees that are paid to composers today."146 Yet, he stated that if he refused to work unless there were no work-made-for-hire clause in his contract, he "would have to consider some other field of work."146

141 See Hearing, supra note 135, at 132-33 (statement of Mr. Robert G. Steele, illustrator); see also Comment, Free Lance Artists, Works Made for Hire, and the Copyright Act of 1976, U.C. DAvis L. REv. 703, 705 n.7 (1982) ("[T]he use of work for hire contracts has increased due to the provisions of the new law.").

142 See Hearing, supra note 135 , at 10 (testimony of Mr. Irwin Karp on behalf of the Author's League of America).

143 Id. at 59 (statement of Mr. E. Gabriel Perle on behalf of the Magazine Publishers Ass'n).

144 Id. at 34 (statement of Ms. Robin Brickman, a member of the Graphic Artists' Guild, who has prepared graphics for Doubleday, Houghton Mifflin, the New Yorker, Horticulture Magazine, Rodale Books, the New York Times, and Little Brown, Inc.). ${ }_{145} I d$. at 73 (testimony of Mr. Elmer Bernstein on behalf of the Screen Composers of America).

${ }^{148}$ Id. at 73. Mr. E. Gabriel Perle, representing the Magazine Publishers Association, disputed the pervasiveness of work-made-for-hire contracts, arguing that "magazine publishers rarely use the work made for hire approach. They do not very often need those rights. And they do not need the hassle that is involved in negotiating for more than they need or want." Id. at 50. Ms. June Roth, president of the American Society of Journalists and Authors, contended, however, that purchase of one-time, North American rights had been the usual practice, but that publishers were changing over to work-made-for-hire contracts with all of their concomitant inequities. Id. at 45. 
The signing of a work-made-for-hire clause designates the publisher as the "author" for purposes of copyright. ${ }^{147}$ Once the publisher becomes the author, she can use the work any way she pleases, ${ }^{148}$ even in ways unanticipated by the artist at the time of the agreement. This allows publishers to further undermine the already tenuous bargaining position of independent artists. For example, Ms. Robin Brickman, a graphic artist, testified that she was commissioned to do interior graphics for a book for Doubleday Books and was told she would either take the work-made-for-hire contract or receive no commission at all. Ms. Brickman accepted the contract after agreeing on the price for the interior graphics and produced and delivered them. Later, Ms. Brickman discovered one of her graphics was used for the cover of the book. ${ }^{149}$ Had she known the publisher intended to make such use of her work, she could have bargained for greater remuneration. ${ }^{150}$ The use of the work-made-for-hire contract allowed Doubleday to get the cover illustration, which would usually cost between $\$ 500$ and $\$ 800$, for the $\$ 75$ paid for the interior graphic. ${ }^{151}$ In addition, Ms. Brickman was displeased with the way the cover illustration was colored by the publisher. ${ }^{152} \mathrm{Had}$ she not been forced to acquiesce to a work-made-for-hire contract for the interior graphics and been able to negotiate about the individual cover graphic separately, she might have been able to retain some minimal artistic control over the coloring, or been able to bargain for compensation for relinquishing such control. The work-made-forhire contract, however, precluded her from ever getting to the bargaining table on such issues. The Joint Ethics Committee, an organization of illustrators, painters, art directors, graphic artists, photographers, and their agents, submitted a statement that, in increasing instances, the imposition of a work-made-for-hire contract on the artist is done after the assignment has been started. ${ }^{153}$ Such a use puts the artist in

147 See 17 U.S.C. $§ 101$ (1982) (subdivision (1)).

148 It also deprives the author of re-use rights. The Association of American Publishers has no sympathy for that position, saying that it is false that artists need re-use rights to stay in business. Rather, according to the Publishers, an artist can simply "use . . . her talents to create other works." Ass'n of American Publishers, Inc., Position Paper 4 (July 1986) (on file with the University of Pennsylvania Law Review). Their response, obviously, does not meet the artists' critique.

140 See Hearing, supra note 135, at 3 (testimony of Ms. Robin Brickman).

150 The Society of Photographer and Artist Representatives, Inc., submitted a statement to the same effect: photographers were being required to sell all rights at onetime prices without the benefit of any negotiation. Id. at 107-08 (statement of Ms. Edith Leonian, Chairperson, Copyright and Industry Practices Committees, Society of Photographer and Artist Representatives, Inc.).

151 Id. at 3 (testimony of Ms. Robin Brickman).

152 Id.

${ }^{15 s}$ Id. at 153 (statement of the Joint Ethics Committee). 
even less of a position to be able to turn down the work-made-for-hire conditions: time, effort, and money are already expended. The unequal bargaining position of the parties, the unqualified nature of the transfer of the rights, and the commissioning party's ability to dictate if and when work-made-for-hire contracts will be imposed on the artist all combine to deprive freelance artists of fair compensation for their works.

\section{Incentives to Produce Creative Works}

The operation of the 1976 Act's commissioned work-made-for-hire provisions also threatens artistic production by creating inducements for authors to produce less than their highest quality work. The San Francisco Society of Illustrators submitted a letter in the 1982 hearings in which it stated that "an artist can, and has, found that a piece originally commissioned (and priced) as a minor work has been extensively used as a major visual ie [sic]: book cover, billboard."154 The Society echoed other artists' concern with failing to receive proper remuneration, but also stressed that such practices penalized the artist for "doing work beyond the expectations of the artbuyer."15s Therefore, the 1976 Act creates a powerful incentive to artists to produce the absolute minimum work required by the commissioning party.

This sentiment was echoed by June Roth, president of the American Society of Journalists and Authors, when she wrote that the mandatory work-made-for-hire contracts permitted by the 1976 Act's provisions created the risk of "losing a healthy flow of superior professional material" with a "sharp and inevitable decline in editorial quality."168 In 1983, a commentator focusing on journalists expressed the same sentiment: "[S]uch further 'insults' as work-for-hire abuses might drive the most intellectually gifted of them into such higher-paying verbally-oriented fields as law and public relations."157 Reducing the quality and quantity of artistic works and the quantity of the "most intellectually gifted" authors contravenes both the declared intent of the 1976 Act ${ }^{168}$ and the constitutional imperative to benefit the public. ${ }^{169}$ Illustrators).

Id. at 130 (letter of Mr. John A. Lytle, President, San Francisco Society of 188 Id.

${ }^{186}$ Id. at 22 (statement of Ms. June Roth, president, American Society of Journalists and Authors, Inc. (citing AMERICAN SocIETY OF Journalists AND AUTHORS, On 'Work Made for Hire': A Statement of Position, 1 (Apr. 28, 1978))).

${ }_{157}$ Note, Journalists' Rights to Their Own Work, 8 ART \& L. 113, 123 (1983).

${ }^{158}$ See supra note 131 and accompanying text.

${ }^{150}$ See supra note 9 and accompanying text. 


\section{Dissemination of Works}

Finally, the 1976 provisions provide a bar to the greatest possible dissemination of artistic works. The ease with which publishers can obtain all future rights in works with work-made-for-hire contracts provides an incentive to secure all those rights, whether they ever intend to reuse the works or not. Once they have purchased a work at one-time rates, and used it, they have no particular motivation to exploit all of the possible uses of the work. In fact, they are more than likely not geared to make profitable use of all the rights they do obtain. The 1976 work-made-for-hire provisions governing commissioned works, thus, keep re-use rights in works from being exploited by those who would push hardest to distribute their works in as many forms as possible: the artists.

Twenty years of apparent compromise resulted in a provision that has harmed both artists and the public welfare. As Philip Leonian, a free-lance photographer, stated, a "compromise is all too often a temporary solution."160 In this case, the compromise was a temporary solution to the theoretical disagreements between legislative drafters, but a positive producer of inequality in practice. The response by many artists has been to join together to push for legislative reform. By 1986, more than forty artist and writer groups representing more than forty thousand artists had coalesced to support reform of the 1976 Act's work-made-for-hire provisions. ${ }^{161}$

\section{B. Legislative Proposals to Change the Work-Made-for-Hire Provisions}

For the past five years, various amendments to the 1976 Act have been proposed that would lessen the disparity in bargaining power between artists and publishers. These reforms would provide greater compensation for commissioned artists, thereby increasing the quality and quantity of artistic creation in the United States. The following discussion highlights some of the ways in which amendments to the provisions governing works made for hire could further the policies intended to be protected by copyright legislation.

160 See Hearing, supra note 135, at 158 (statement of Mr. Philip Leonian, freelance photographer).

${ }^{161}$ S. 2330 , 99th Cong., 2d Sess., 132 Cong. Rec. $\$ 4483$ (daily ed. Apr. 17, 1986). Grassroots coalitions of artists have led the lobby for legislative change. Artists have gone to Washington to lobby in person and instituted letter-writing campaigns. Telephone interview with Ms. Margi Trapani, Graphic Artists Guild (Nov. 21, 1986). The growth of the artists' guilds has been attributed to the work-made-for-hire controversy. See Hearing, supra note 135, at 34 (testimony of Ms. Robin Brickman). 


\section{Preventing the Aldon Accessories Outcome}

In light of the potential for inequitable treatment that exists whenever a commissioned work is considered a work made for hire, Congress should take steps to limit the application of the work-made-forhire provisions to the circumstances originally envisioned in the 1976 Act. The first step in any reform of the work-made-for-hire provisions, therefore, would be to amend the Act in a manner that would, in effect, overrule the interpretation of the work-made-for-hire definition in section 101 that has been adopted in cases such as Aldon Accessories. ${ }^{\mathbf{1 6 2}}$ Congress is, in large part, responsible for this misinterpretation of the work-made-for-hire provisions. In both the 1909 Act and the 1976 Act, it refused to provide a guiding definition of "employee" or "employer," thus leaving courts with unfettered discretion to determine the operation of the work-made-for-hire provisions. This failure, noted in the legislative history of the 1909 Act, ${ }^{103}$ must be remedied if the intent of the drafters of section 101 is to be effected.

One proposed remedy of Congress's omission is to borrow a definition of "employee" from another statute. For instance, an "employee" could be defined as one who receives employment benefits required by law and whose employer withholds taxes from salary. ${ }^{\mathbf{1 6 4}}$ With such a qualifying definition, the Aldon Accessories court's transformation of works by types of independent contractors not listed in subdivision (2) into subdivision (1) "employee" works would not be possible. Without such a definition, efforts by artists to have types of commissioned works deleted from subdivision (2) are essentially pointless; ${ }^{\mathbf{1 6 5}}$ as long as the Aldon Accessories interpretation is possible under the language of the Act, removal of types of works from subdivision (2) will not prevent those works from being designated as works made for hire. Insertion of a definition of "employee" is a prerequisite to redefining the scope of subdivision (2).

\section{Unfair Compensation and Unequal Bargaining Power}

Providing a definition of "employee" will only limit the number of artists potentially subject to having their works classified as works

162 See supra notes 93-130 and accompanying text (discussing cases).

$16 s$ See supra note 19 and accompanying text.

164 Such a provision was proposed in S. 2330 , supra note 134 , at $\S 1$ (A) and S. 2138 , supra note 133 , at $\S 2(1)$.

${ }_{185}$ Such efforts are a major part of many copyright reforms. See, e.g., S. 2330, supra note 134 , at $\S 1$ (B); S. 2138 , supra note 133 , at $\S 1$; and S. 2044 , supra note 132 , at $\S \S 1-3$. 
made for hire; for those independent contractors whose work product still comes within the scope of subdivision (2), additional reforms are needed. The most straightforward reform would be to delete subdivision (2) ${ }^{166}$ in addition to providing a definition of "employee." Therefore, no commissioned works would be works made for hire. One commentator has argued that this would "arm the author with the copyright as he went into the negotiating room. . . . [and] at least subject [the publisher's] superior bargaining power to more challenges."167 Theoretically, then, artists might be afforded some protection from publishers bargaining for an avowed purpose of the artwork and then using the work for another purpose, assuming that bargaining for individual rights would entail bargaining for particular uses. Such a proposal, however, would not prevent publishing houses from extracting allrights contracts from the authors. Because publishers are in a superior bargaining position, as long as artists can contract their rights away, publishers will be able retain the upper hand in all contract negotiations. ${ }^{168}$ There is no reason to believe that they will bargain any more explicitly for individual rights under an all-rights contract than they have under work-made-for-hire contracts.

To remedy this type of injustice, deletion of subdivision (2) would have to be coupled with a requirement that contracts explicitly state the publisher's intended uses of the work, ${ }^{169}$ and/or that transfers of rights

${ }_{188}$ Deletion of all commissioned work categories except for motion pictures was proposed in S. 2330, supra note 134, at $\S 1$ (B). For discussion of why other proposals have continued special treatment for motion pictures, see Colby, Copyright Revision Revisited: Commissioned Works as Works Made for Hire Under the United States Copyright Act, 5 WhitTIER L. Rev. 491 (1983) (defense of work made for hire in movie-making industry by Senior Distribution \& Marketing Counsel of Twentieth Century-Fox Film Corporation); Fischer, Work Made for Hire Revisited, 5 CopYRIGHT MGMT., Apr. 1982, at 4-5 (1981) ("In motion pictures there are many possible creators of works of authorship-screenwriters, directors, cinematographers, actors, and others. Work made for hire is a valuable means of synchronizing these possible claimants under one copyright scheme.").

France has chosen an approach to audiovisual works that falls halfway between the work-made-for-hire approach and the laissez-faire contractual approach. New French law "decrees in behalf of the producer of an audiovisual work a presumption of transfer by authors of their exclusive exploitation rights in the work concerned." Françon, The Audiovisual Production Contract, 127 Revue InTERnationale Du Droit D'AuTEur 70, 76 (1986). Thus, absent contrary contractual provisions, French courts will presume transfer of rights in an audiovisual work from the artist to the commissioning party. The law, however, in an attempt to protect authors' interests, delineates the amount to be paid to authors and who should pay authors. See id. at 84-92. The law also requires producers to provide accounting to authors. Id. at 92 . Whether this law "strike[s] a balance between the opposing interests of producers and artists" as hoped is yet to be seen. Id. at 100 .

${ }_{167}$ Note, supra note 157, at 123.

168 See Hearing, supra note 135, at 10 (testimony of Mr. Irwin Karp).

${ }^{168}$ Senate bill 2138, for example, proposed that, for works of the type that bill 
are deemed not to exceed the parties' reasonable expectations of use. ${ }^{\mathbf{1 7 0}}$ Under such a requirement, for example, Ms. Brickman's transfer of the right to use her graphics as internal graphics could not have rightfully been parlayed into transfer of the right to use them on the cover. ${ }^{171}$ Therefore, Doubleday's use would have constituted infringement, and Ms. Brickman would have been entitled to sue to recover the compensation wrongfully deprived her.

What would these reforms achieve for artists? Besides providing the artists with more opportunities to bargain and more information with which to bargain, it would provide them with the ability to terminate their grant of copyright pursuant to section 203. ${ }^{172}$ As long as their works are designated as works made for hire, artists can never regain rights to their works. If their works are not works made for hire, however, authors could terminate the hiring parties' rights after thirtyfive or forty years. The right to termination would provide authors with a right to exploit, and thereby earn compensation from, works for which they received the equivalent of one-time use rates and which then had unexpectedly prolonged vitality. ${ }^{173}$

proposed to delete from subdivision (2), transfer of rights could only occur in a "written instrument [signed by both parties] specifically enumerating each right." $\mathrm{S}$. 2138, supra note 133, at $\S 2(2)$. Cf. Françon, supra note 166, at 80 (French audiovisual law specifies that "audiovisual production contracts shall not imply assignment to the producer of the graphic rights and theatrical rights in the works," thereby requiring specific enumeration of rights beyond audiovisual rights.).

170 Senate bill 2330 called for a similar variation on the German "transfer purpose theory." See S. 2330, supra note 134, at $\S 2$; cf. Black, The Regulation of Copyright Contracts: $A$ Comparative View, Eur. InTEll. Prop. Rev. 386, 387 (Dec. 1980) (describing the German "tranfer purpose theory"). Senate bill 2330, however, would only have looked to the transferee's reasonable anticipation of use.

The reasonable expectations test does pose some potential difficulties for the independent artist. Unlike the termination provisions, which can be effected without litigation, a reasonable expectations clause invites litigation. In general, cases involving interpretation of the scope of the grantor's grant have come down in favor of the grantee. See, e.g., Bartsch v. Metro-Goldwyn-Mayer, Inc., 391 F.2d 150, 154 (2d Cir. 1968). Yet, the court's broad reading of grants by grantors has occurred absent restrictive statutory language. A reasonable expectations clause should curtail overbroad reading of intended grants even though it might not help the artist in a close case.

171 See supra notes 149-53 and accompanying text (describing the experiences of Ms. Brickman).

${ }^{172}$ See 17 U.S.C. $\S 203(a)(3)(1982)$ (providing that "[t]ermination of the grant may be effected at any time during a period of five years beginning at the end of thirtyfive years from the date of execution of the grant; or, if the grant covers the right of publication of the work, the period begins at the end of thirty-five years from the date of publication of the work under the grant or at the end of forty years from the date of execution of the grant, whichever term ends earlier").

${ }^{173}$ Senate bill 2138 contained a provision that would have allowed an independent contractor to bring an action to reform or terminate the transfer of a copyright where the profits earned by the transferee were strikingly disproportionate. See S. 2138 , supra note 133 , at $\S 2(3)$. That proposal was opposed by the American Bar 
The publishers have vigorously opposed even this modest reform. ${ }^{174}$ The Association of American Publishers has argued that in the case of encyclopedic works and instructional texts "subjecting discrete segments of larger interwoven units . . . to myriad terminations of the publisher's rights would be virtually intolerable."176 Even though few commercial works are likely to retain their vitality after thirty-five years, they are apparently concerned with the administrability of a termination system and the possibility that they could lose rights to portions of a finished work, thereby damaging the larger work. In an era of computers and massive blanket licensing agreements, the administrability concern is not compelling. ${ }^{176}$ Superficially, publishers' concern with the ongoing integrity of their larger works is more compelling, but the possibility of termination only requires that the publisher bargain a second time with artists whose works have remained valuable beyond the thirty-five or forty years. Hence, the publishers' objection is not that their larger works are at risk, but rather that they will have to pay for use beyond thirty-five or forty years, "robbing" them of the windfall they currently enjoy when a commissioned work achieves unexpected long-term vitality. ${ }^{177}$ Thus, the deletion of subdivision (2) could ensure commissioned artists a greater likelihood of receiving the true lifetime value for their works. Their compensation would more accurately reflect their actual contributions to society.

Two other legislative changes would be necessary to completely rectify the artist's inability to bargain for fair compensation. First, Congress should adopt an amendment requiring that contracts for transfer of rights be entered into prior to commencement of the work so that the publishers cannot extract more than anticipated rights after the artist has already spent time, money, and effort on the work. ${ }^{178}$ Second, as

Association and publishers largely on the grounds that a similar proposal had been made during the copyright revision as early as 1961 as an alternative to the termination provisions and had been defeated. Telephone interview with Tad Crawford, Counsel, Graphic Artists Guild (Jan. 29, 1987).

${ }_{174}$ See, e.g., Hearing, supra note 135, at 120 (statement of Ms. Bella L. Linden on behalf of Harcourt Brace Jovanovich, Inc.).

${ }^{175}$ Id. at 69 (statement of the American Ass'n of American Publishers, Inc.).

176 The accounting required for the termination procedures would entail nothing more that keeping a record of who produced what on a given date. Termination is initiated by the artist; the publisher's recordkeeping is not necessary to effect termination transfers, but only for a defense to an attempted termination. It might also be possible to develop a blanket licensing system. See Note, supra note 140, at 1245.

${ }_{177}$ For example, a publisher will end up paying more for a work, the value of which was initially underestimated, if she is required to renegotiate the transfer after 35 years.

${ }^{178}$ See supra note 148-52 and accompanying text (describing this bargaining tactic of publishers). Senate bill 2138 included such a provision. See S. 2138, supra note 133 , at $\S 2(2)$. 
will be discussed shortly, an early termination provision for uses contracted for but not exercised within a certain period of time would enable artists, and society as a whole, to more fully enjoy the fruits of the artists' labors. ${ }^{178}$

\section{Incentives to Greate}

Under the 1976 Act's commissioned work-made-for-hire provisions, artists have been discouraged from producing the best works they can and even from working as artists at all. ${ }^{180}$ The most significant difficulty is that the publishers can remunerate an artist for the least valuable aspects of her work, step into the artist's shoes as "author" through the work-made-for-hire contract, and then put the work to more valuable uses. This is a powerful disincentive to the production of high quality, multi-use works.

Under United States copyright law, which does not explicitly recognize moral rights, incentive is primarily posited in economic terms. Thus, the legislative correction that ensures the artists' remuneration is fair would also restore incentive. Assuming that a definition of "employee" is appended to the work-made-for-hire provisions, and that subdivision (2) is deleted, the most effective way to meet the commissioned artists' incentive problem would be to insert a reasonable expectations clause similar to the one mentioned above. The transfer of userights should not exceed the uses the parties reasonably anticipate to be exercised. ${ }^{181}$ This would provide artists with a weapon against unscrupulous publishers, who explicitly bargain for a less expensive use than they intend to implement.

Congress should also consider a disclosure requirement for publishers. If publishers were required to list their anticipated uses of a work, that list could provide a crucial element of the factual basis for the parties' reasonable expectations. Such a disclosure requirement, however, is unlikely to be effective by itself. Publishers would, in all likelihood, respond to a disclosure requirement in the same way they responded to subdivision (2): by producing standardized contract terms. In the case of disclosure, they could list every possible use ever to be contemplated for a type of work or they could describe the uses so

178 See infra note 185 and accompanying text.

180 See supra notes $154-59$ and accompanying text.

181 See supra notes 169-171 and accompanying text. This treatment of transfers is analagous to the shop-right doctrine found in patent law. A shop-right theory was proposed during the 1976 Act's drafting, but not incorporated into the final draft. See Gallay, supra note 79, at 578 (under shop-right doctrine, employer may use a work only for business activities; other uses are reserved to the employee). 
vaguely that any type of use would be covered. Thus, while a disclosure requirement might reduce some of the burden on the artist trying to prove the parties' expectations, it is unlikely to be very effective. The essential legislative change required to restore proper incentives to artists to produce is the insertion of a reasonable expectations test.

\section{Dissemination}

For the public, the greatest harm produced by the 1976 Act's commissioned work-made-for-hire provisions is the potential reduction in the dissemination of artworks. Indiscriminate use of work-made-forhire contracts leads inevitably to the stockpiling of works by publishers. As was stated in the 1982 Hearings, the work-made-for-hire provisions "ultimately inhibit the free flow of ideas and information which is so precious to all Americans."182 Thus, legislative change is necessary to free those works not being used by publishers that the artists would promote if they had rights in them.

By defining the term "employee" and deleting subdivision (2), Congress could restore to commissioned artists copyright in their works. Artists, therefore, would have termination rights after thirty-five or forty years, ${ }^{183}$ and thus publishers' stockpiling would be reduced from the present term of seventy-five years for works made for hire. ${ }^{184}$ In the case of the publisher, who only uses the work one time, though, that still leaves more than thirty years for a work to lie dormant. Furthermore, even if a publisher exercises a use of the work for thirty-five years, there may be many other uses for the work that remain unused for more than thirty years. Thus, a termination provision that could be effected by the commissioned artist for specific uses and in a shorter time span is required if the public is to benefit from the greatest possible dissemination of artworks. Any right to usage not exercised by a publisher within a five-year period, for example, could be subject to termination by the artist. ${ }^{185}$ Thus, artists could free works that otherwise might languor unused in hiring parties' warehouses or computers.

In summary, five legislative changes need to be undertaken if the inequities produced by the 1976 Act's work-made-for-hire provisions

182 See Hearing, supra note 135, at 21 (statement of Ms. June Roth, president, American Society of Journalists and Authors, Inc.).

183 17 U.S.C. \& 203(a)(3) (1982).

18417 U.S.C. $\$ 302(c)(1982)$.

185 Senate bill 2330 provided that "a partial termination may be effected at any time during a period of five years beginning at the end of the period of three years after the date of the execution of the grant. The termination shall apply to any usage permitted under the grant which has not been exercised by publication . . . " S. 2330, supra note 134 , at $\S 4$ 
are to be corrected: (1) insertion of a definition of "employee" into subdivision (1); (2) deletion of subdivision (2); (3) insertion of a reasonable expectations clause; (4) insertion of a clause requiring that contracts be entered into prior to initiation of the work; and (5) insertion of a termination of individual use-rights provision.

\section{CoNCLUSION}

Almost ten years have passed since the 1976 Act went into effect. Now is a logical point at which to pause and take stock of how the Act is working. This Comment has evaluated the 1976 Act's definition of commissioned works made for hire found in section 101 and how that definition has been judicially interpreted and practically implemented.

While some courts have interpreted the definition of works made for hire found in section 101 consistently with its legislative history, the court in Aldon Accessories and its progeny misinterpreted the definition of commissioned works made for hire. Congress intended to limit application of the work-made-for-hire doctrine to commissioned works in two ways: (1) by limiting the categories of commissioned works available for work-made-for-hire status by specifically enumerating only those categories eligible; and (2) by requiring a written agreement signed by both parties designating the work as a work made for hire. The Aldon Accessories decision undercut both requirements by designating statuary as works made for hire, even though statuary does not fall into one of the nine enumerated categories and the hiring party and the contractor signed no contract designating the work as a work made for hire. The court in Aldon Accessories had strong reasons, practical and equitable, to find that the plaintiff was the author of a work made for hire. Yet, its interpretation of the provisions opened the way for creators of commissioned works to lose rights in their works even when they had signed neither a work-made-for-hire agreement nor an assignment-of-rights agreement. The fact that the Seventh Circuit adopted its reasoning without discussion makes this potential threat even more disturbing.

The practical operation of the 1976 Act's commissioned workmade-for-hire provisions has also contravened the purposes of copyright legislation. With the widespread implementation of standard workmade-for-hire agreements, it has become more difficult for artists and authors to get fair remuneration. That, in turn, has reduced the incentive for authors and artists to produce their best works or even to remain artists at all. Finally, the work-made-for-hire standardized contracts have created the potential for publishers' stockpiling of artworks, thereby reducing the greatest possible dissemination of works. 
Legislative change is required if these concerns are to be met. Above all, Congress must provide a definition of "employee." The term is crucial to proper interpretation of the work-made-for-hire provisions. The 1909 Act's drafters avoided the task as did the 1976 Act's drafters. The time has come to clarify the law for artists, publishers, and courts alike. Such an amendment would go far toward remedying the ill effects of the Act's practical impact and the judicial misinterpretation.

In addition, Congress should consider deleting commissioned works from the work-made-for-hire provisions altogether. If Congress did, commissioned artists would still be subject to imposition of allrights contracts by publishers. Then, to even the widely disparate bargaining powers of the individual authors and the publishers, Congress should add two more provisions: (1) a reasonable expectations clause and (2) a short-term termination provision for individual use-rights in a work.

Copyright legislation is passed pursuant to the constitutional directive to "secur[e] for limited Times to Authors . . . the exclusive Right to their respective writings." 186 Legislative reform is necessary to restore to independent artists rights in their works. Absent reform, the "compromise" reached in the 1976 Act's work-made-for-hire provisions will continue to work in favor of the publishers and against artists. 